\title{
The Hypertextual Dialogue between Living History and True History
}

\author{
Two Perspectives from \\ the World Wide Web on the Holocaust
}

\author{
Maria Mattus
}

The World Wide Web offers almost unrestricted freedom of speech. Consequently, this large marketplace of ideas ${ }^{1}$ contains all kinds of information including plagiarism, falsifications, and incorrect data. Sometimes, web information is considered problematic, or even dangerous, because of its possible influence on the readers' thoughts and acts, but, "dangerous" information is not necessarily related to issues like pornography, racial hatred, blasphemy or bomb-making. The presence of misleading, unreliable or indefinable information might be a problem that is even more difficult to survey. Since we are expected to collect an increasing amount of information from the World Wide Web, what information can we use and trust?

This study shows that the freedom of the World Wide Web can provide great opportunities for some actors, but it can also mislead the readers. Living History, a serious information campaign, supported by the Swedish government, was plagiarised by an anonymous web actor, True History, which presented conflicting opinions. This plagiarism gave rise to an interesting kind of interaction between these two actors, whose inequality as regards their positions and resources would certainly be more noticeable in other arenas.

The concept hypertextual dialogue is chosen to describe the above interaction. The first part, hypertextual, refers to the structure on the World Wide Web, but also to the intertextuality that unites texts from different sites and makes them interrelated and part of the same discourse - the term hypertext can be used to apply to both the structure and the content. In this study, the latter aspect is focused. The second part of the concept, the dialogue, refers to a definition used by Linell (1998:9): "any dyadic or polyadic interaction between individuals who are mutually co-present to each other and who interact through language (or some other symbolic means)". A hypertextual dialogue takes place in an arena, like the World Wide Web, where the actors interact more or less deliberately in several ways.

The aim is to identify some kind of hypertextual dialogue between the two sites on the World Wide Web, and to find out,

- how the texts become interrelated and part of the same discourse;

- how the reproduction and recontextualisation of words or text segments cause a change in the meaning of the message; 
- how the actors interact and affect one another;

- how the actors describe their own and the other's identities.

\section{Methodological Considerations}

The method chosen for this study is textual analysis inspired by rhetoric together with theories of dialogism. Texts from two different web sites are examined and compared. One of these sites uses the Holocaust as a point of departure to encourage a discussion about humanity, democracy, and equality. The other site represents a revisionist ${ }^{2}$ ideology that regards the Holocaust as a myth, and is not prepared to accept the official depiction of the Holocaust.

As a background to the empirical data, the method will be described, followed by a short discussion about some issues related to hypertext as data.

\section{Textual Analysis of a Relationship}

When we want to affect someone to bring about a change, no matter if it is in an official speech, through advertising or in an everyday argumentation, a knowledge of rhetorical mechanisms and tools is useful to us. Cassirer (1997:104) catches the core of rhetoric in the following question: "Who says what, where, to whom, when and in which way, with what effect?" This formulation could also correspond to the description of a classical linear communication process ${ }^{3}$, in which the sender transfers a message through a channel to a receiver with the intention of changing behaviour or attitude (Fiske 1997). Linear transfer models of communication, as well as rhetoric, propose that the communication, or persuasion, process can best be understood step by step. Successful communication takes place if the message arrives at the destination as intended - when the effects seem to correspond to the sender's expectation or aim. Certainly, in approaches like these, the process is greatly simplified and many dimensions of interaction are excluded. The transfer models treat communication as a "from-to" process, which, according to Linell (1999), also can be seen as monological. He emphasises the necessity of a dialogical perspective to understand communication as a "between process" - a process in which the parties share knowledge, mutually provide evidence, and establish an intersubjectivity.

Karlberg and Mral (1998) declare that rhetorical analysis has a holistic perspective. Its aim is the production, the contents, and the reception of a persuasive message, but the social context and the rhetorical situation serve as points of departure for the analysis. The purpose is to understand the construction of speech, or text, with a persuasive function, by taking into account the wholeness ${ }^{4}$. Rhetorical analysis does not offer any standard procedure to follow - each single analysis has to be adjusted according to the prevailing conditions. Karlberg \& Mral present a model for analysis that can be used on various media texts.

The process of persuasion presupposes human interaction. In the following textual analysis, rhetoric is used as source of inspiration, but some of the ideas of dialogism also serve to emphasise the dialogue and the actors' influence on one another. For instance, concepts from Bakhtin and Goffman have encouraged the dialogical approach. Further, rhetorical analysis is an interpreting method that does not exclude the impact of other theories, and this makes it possible to use rhetoric in a more exploratory way. 


\section{Where Is the Text in Hypertext?}

The strongest attribute of the World Wide Web text is its ability to use links and to move from one point in a text to another. Today, links between words, or segments of text, appear natural in this context (Mitra \& Cohen 1999).

Conventional text printed on paper has a clear axis of development, from beginning through middle to end. Hypertext, however, does not have this dominant axis and does not flow in a single direction.

The term "hypertext", coined in 1963 by Theodore Nelson, was first used to refer to "non-sequential writing". In science, except for medicine and psychology, the prefix "hyper-" connotes extension and generality. According to Snyder (1997:24), hypertext initially encompassed "texts that are minimally or maximally non-linear and tightly or loosely structured" meaning in a broader sense that all texts could be regarded as hypertext. A more appropriate definition today might be that "[h]ypertext is essentially a network of links between words, ideas and sources that has neither a centre nor an end" (Snyder 1997:18).

The hypertextual structure, or rather lack of structure, promotes intertextuality. Fairclough (1998:84) describes "intertextuality" as the property texts have of being full of snatches of other texts, which may be explicitly demarcated or merged in, and which the text may assimilate, contradict, ironically echo, and so forth". This approach does not especially allude to hypertext or the hypertextual structure, but obviously the connections between intertextuality and hypertextuality are strong. When texts become interrelated, the meaning of a single text depends on other texts, and on the links that have been used. The same text can be understood in several ways. One aspect of this phenomenon, expressed by Landow (1992:53), is that electronic linking also "disperses 'the' text into other texts", and that this process weakens any sense of textual uniqueness.

Bakhtin (in Fairclough 1998:84) has chosen the chain as a metaphor to illustrate intertextuality: "[texts] always constitute additions to existing 'chains of speech communication' consisting of prior texts to which they respond". Further, these chains are attached to the historical, cultural, and institutional settings in which they appear. If a single utterance, or a single text, actually consists of a multitude of voices, Bakhtin's fundamental question seems legitimate: "Who is doing the talking?" However, since there might be a lot of different voices involved, the answer is probably quite complicated. This approach focuses on the dialogicality, and multiplicity of voices, in speech and text.

The meaning of a text is not fixed, or "there"; instead the production of meaning is grounded in a process of dialogicality, which takes place in interactions: On the one hand, it takes place in the sender's struggle with thoughts, words and formulations, involving the interplay with other texts. On the other hand, it takes place in the receiver's efforts in assigning meaning and creating an understanding, which somehow fits the contexts given, and the purposes, which are relevant to him or her (Linell 1998).

The dialogical approach, in which many different voices can be seen, apparently fits in on hypertext, and today Bakhtin's ideas are discussed in a new context. Hypertext on the World Wide Web, with its intertextual character, illustrates the complexity of different voices, the interplay between these voices, and the co-production of meaning.

Analysis of hypertext brings up questions concerning limitation, direction, and order. Further, the transient nature of hypertext has to be considered - in some regard, hypertext might be closer to speech than to written text. Hypertext printed on paper to facilitate the analysis is comparable with a snapshot in which a frozen and strictly demarcated moment has been caught. 


\section{A Description of the Empirical Data}

In an attempt to catch some hypertextual aspects in the analysis, texts from two interacting web sites are analysed and compared. The relationship between these sites, both between the actors and between the texts, has been examined with the intention of taking in consideration the dialogue, or the multivoiced orientation, present in the text.

\section{Living History and True History}

In January 1998, Living History, in Swedish Levande Historia, opened a web site to inform people about the Holocaust and the Nazi terror during World War II. The initiator of this information campaign was Prime Minister Göran Persson, and the Swedish government supported it. According to the information in English, the project consisted of four parts: political manifestations, information to parents and the general public, activities in schools, and support for universities and the research community. The purpose was "to encourage discussion of issues relating to humanity, democracy and equality, using the Holocaust as a point of departure" ${ }^{5}$. Part of the campaign was also the distribution of a book, entitled "Tell ye your children..." (...om detta må ni berätta...). The book is offered free, and parents of schoolchildren in particular are invited to order it.

The web site offers a comprehensive selection of information about the Holocaust, including facts about the Nazi terror, the testimony of survivors, life-stories of victims, research findings, recommended literature, issues to discuss in school, addresses of individuals and organisations working with the project, and links to other web sites of interest to the readers. The aim is also to establish a stimulating meeting place for teachers, students, and anyone else interested in the subject. Consequently, interactivity on the web site is promoted in different ways, for example e-mail contacts with people involved in the project and the exchange of ideas between teachers at seminars.

Later, in the autumn of 1998, someone plagiarised the site on the World Wide Web. The plagiarism was named True History, in Swedish Sann Historia, but had chosen an almost identical web address as Living History, only the final part differed. Living History used the address "www.levandehistoria.org", while the plagiarism used "www.levande historia.com". Furthermore, the design, typography and colours (black and yellow) were strikingly the same, but the aim was quite different. In the plagiarism the Holocaust was questioned and revisionist ideas were expressed. Survivors and witnesses of the Holocaust were pointed out as liars and their stories were criticised and questioned: "Our well-researched evidence is supported by irrefutable scientific documents, whereas their evidence is based on unreliable stories from traumatised war-time witnesses" $"$. The name True History also showed a certain degree of self-confidence.

When the plagiarism was detected, Living History successfully tried to stop it. A warning on the original, and a press release, informed readers about the purpose of True History and its revisionist ideas. Even so, after being removed from the World Wide Web, the web site emerged again ${ }^{7}$, now in blue and yellow like the Swedish national flag. The same web address, www.levandehistoria.com, was used, and still is.

The size of the Living History web site, compared with the site of True History, was quite imposing. In February 1999, the plagiarism contained about 10.000 words, but Living History was at least eight times that as long ${ }^{8}$. 


\section{In Search of a Dialogue}

Three objects from each of the two sites have been chosen. These texts are connected in different ways, and will be analysed in pairs with one from each site, to look into the relationship between the texts. Different aspects are examined in the analyses: the change in meaning when some of the original words are replaced, the presentation of self and of the other, and the usage of isolated text segments from the other site.

First, the pages that rhetorically serve as introductions to the sites ${ }^{9}$ are analysed. True History plagiarised most of its contents from Living History, and this page could be seen as the actual plagiarism. Consequently, the texts Living History and True History present on these pages are very similar, but the words that do not correspond make a great difference. After the description of the two pages, the plagiarism is compared with the original text.

In the second case, a press release from the Living History site, together with the explanation True History gave of why the site was removed, have been chosen as objects for the analysis. This is the only time Living History mentions the revisionist site. The emphasis will be on the self-presentations and on the descriptions of the other site.

Finally, Living History presents a testimony from Emerich Roth, one of the survivors of the Nazi camps, and True History criticises the authenticity of this testimony in an open letter. The letter is addressed to Living History, especially to Emerich Roth, and it calls in question not only his testimony, but also the entire Holocaust. True History invites Emerich Roth to publish a reply, or rather an apology, on their web site. The quotations and arguments used by True History are emphasised in the analysis.

\section{Genre and Relationship Between the Sites}

Living History belongs to a genre one could to describe as information, or enlightenment. The web site provides the readers with facts, experiences, research findings, literature and films, issues to discuss et cetera. Survivors and witnesses from World War II play important parts. The message is that within a few years, those who experienced the Holocaust will be gone, and we have to listen to them now. There is also an element of justice involved in Living History: On the one hand, accusing the Nazis of one of the most carefully organised ethnic cleansings in modern times, and, on the other, defending and protecting the authenticity of the material, as well as issues of democracy and humanity.

True History presents itself as "opposed to Living History", and by exploiting revisionist ideas, True History questions Living History. The criticism is directed at the Swedish government, as promoter of the campaign, and especially at the Prime Minister as the initiator. Further, accusations are made against survivors, witnesses, researchers, and others maintaining the Holocaust myth. The issue of freedom of speech is also on the agenda. True History declares that "free speech generates healthy debate", but what kind of debate do they encourage?

True History is linked to Living History in various ways. Obviously, the plagiarism presupposes that the original is available on the World Wide Web. The presence of links to Living History, and the fact that the project is mentioned several times in the texts, indicates this. However, the relationship is not interdependent. The mission of True History would certainly not be the same if Living History were to disappear, while the existence of Living History is not dependent on True History, though each is influenced by the presence of the other. In the press release, Living History calls attention to the plagiarism, an act that might even favour the other side. Consequently, the two sites interact 
more or less deliberately: when True History attempts to start a dialogue about ideas, and arguments, Living History just touches upon the relationship in its press release. The desire for a dialogue is definitely not mutual, and the contributions to the dialogue might be unbalanced or asymmetrical, since the actors are aware of each other and their acts are affected by the other part. Dialogues can be seen between the two actors, but also in separate texts, in which different voices appear.

\section{The Senders and the Receivers}

The communication process includes a sender and a receiver, and both can participate in the construction of meaning. In this case, the senders are called "actors" since they are actors on the World Wide Web.

The Swedish government supports Living History, and that makes correctness and accuracy of particular importance. Influential representatives of Swedish society, including leaders of all the parliamentary parties, are said to be involved to further strengthen credibility. To facilitate contacts the web site contains several names, addresses and links to engaged individuals, associations, parishes, project groups et cetera. However, a project "supported by the government" does not give any guarantee of trustworthiness.

Except from the signature on the open letter to Living History, True History does not mention any names of individuals involved in the project. Individuals or organisations supporting the site do not come forward. However, one single group is mentioned: Sann Historia Free Speech Committee, but in the absence of further information this group remains quite insignificant. Comments can be sent to a webmaster ${ }^{10}$. Names presented in the texts are usually used to identify survivors and witnesses as liars. There is also a list of names, in alphabetical order, of victims who are persecuted in their native countries, or somewhere else, but what they have in common seems not very clear.

The receivers, or the readers, of a web site can be divided into two groups. Karlberg (1998) has noticed that there are those who are just passing through on their way to something else, and those who are looking for something specific they want to know more about. To catch the interest of the first group might be difficult, because the incidental guests can be more interested in the links than in the content. Living History probably wants to catch both groups of readers. Readers who are very interested are able to enter deeply into the subject, and those with only a passing interest can browse the pages to form an idea of the contents. True History seems to focus on the interested, or already convinced, group of readers - the introduction to the site indicates this: "If the content of the present web site displeases you, we invite you to surf elsewhere".

\section{Analysis 1: Small Changes Make a Great Difference}

The excerpts below, one from Living History and one from True History, show some of the problems related to hypertext on the World Wide Web. Since True History has borrowed some 85 percent of the words in the original text, there is no doubt that the plagiarist is familiar with Living History. Just a few words are changed, but they make a great difference. Both the contents and the design on the Living History page have been extensively plagiarised.

Initially, the text from Living History is analysed, and then the plagiarism is compared with the original to see how these small changes might affect the general impression. In the following excerpts, the corresponding words are in boldface. 


\section{Living History (Levande Historia)}

Emmerich Roth, Magda Eggens and Sofia Taikon have all survived the hell on earth - the Nazi concentration camps during World War Two. Their experiences - which you can read about on this web site - give a terrifying picture of what can happen when there is no respect for human worth and when democracy is dismantled.

The Holocaust is frightful evidence of what can happen if we do not keep alive the debate about democracy and human equality. Through knowledge and discussions we can ensure that nothing like this ever happens again.

For this reason Prime Minister Göran Persson has taken the initiative for a general information campaign about the Holocaust. History must be kept alive.
Text in Swedish:

Emerich Roth, Magda Eggens och Sofia Taikon har alla överlevt helvetet på jorden - nazisternas koncentrationsläger under andra världskriget. Deras öden - som du kan följa på denna hemsida - ger en skakande bild av vad som kan hända när respekten för människovärdet upphör och demokratin monteras ner.

Förintelsen är ett skrämmande bevis på vad som kan hända om vi inte håller debatten om demokrati och människors lika värde vid liv. Genom kunskap och diskussion kan vi motverka att något liknande händer igen.

Därför har statsminister Göran Persson tagit initiativ till en bred informationsinsats om Förintelsen. Historien måste hållas levande.

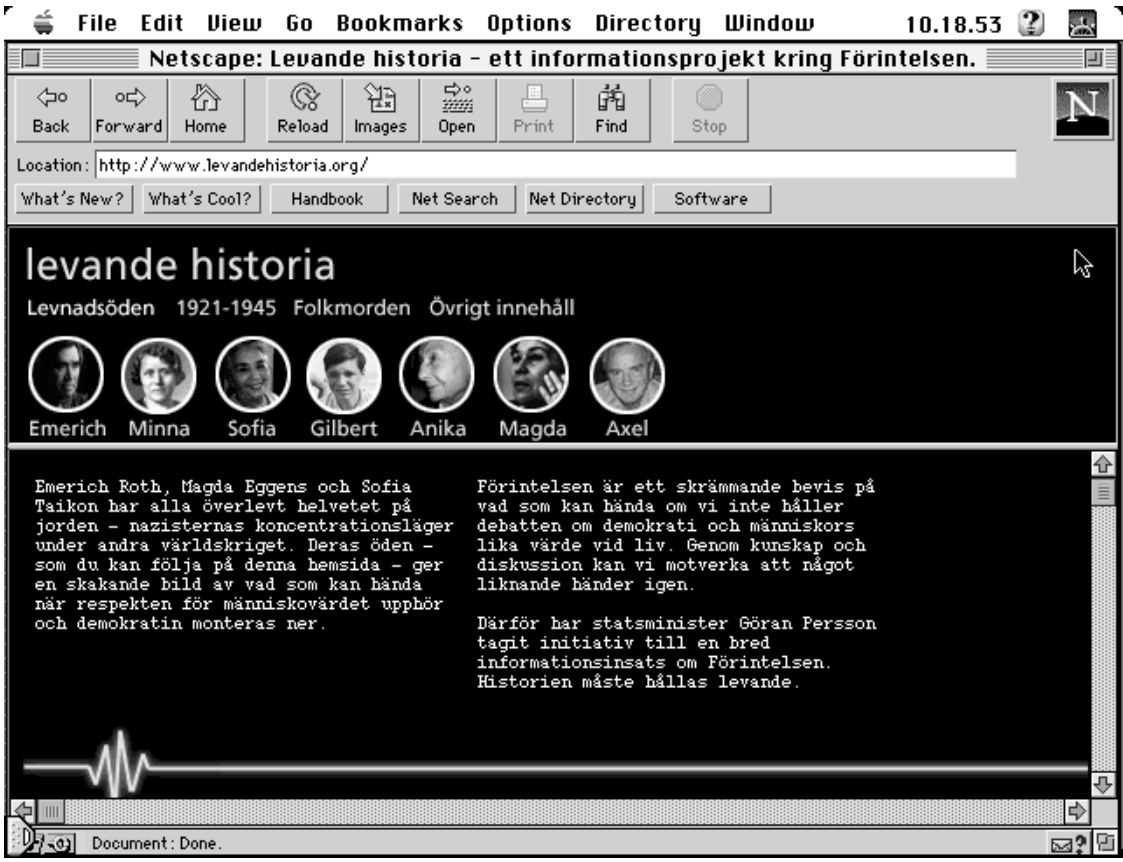




\section{True History (Sann Historia)}

Mel Mermelstein, Elie Wiesel, Simon Wiesenthal, Rudolf Vrba and Filip Muller have all survived the "hell" on earth as "eyewitnesses" of the gas chambers in the Nazi concentration camps during World War Two. Their experiencee which you can read about on this web site - give a terrifying picture of what can happen when there is no respect for the truth and when democracy is dismantled.

"The Holocaust" is frightful evidence of what can happen if we do not keep alive the debate about truth and falsehood. Through knowledge and discussion we can ensure that nothing like this ever happens again.

For this reason our unsuspecting Prime Minister Göran Persson has not taken the initiative for a general information campaign about our version of the "Holocaust" paid for by the Swedish taxpayers' money.
Text in Swedish:

Mel Mermelstein, Elie Wiesel, Simon Wiesenthal, Rudolf Vrba och Filip Müller har alla överlevt "helvetet" på jorden som "ögonvittnen" till gasningar i nazisternas koncentrationsläger under andra världskriget. Deras öden - som du kan följa på denna hemsida - ger en skakande bild av vad som kan hända när respekten för sanningen upphör och demokratin monteras ner.

"Förintelsen" är ett skrämmande bevis på vad som kan hända om vi inte håller debatten om sanning och lögn vid liv. Genom kunskap och diskussion kan vi motverka att något liknande händer igen.

Därför har vår aningslöse statsminister Göran Persson inte tagit initiativ till en bred informationsinsats om vår version av "Förintelsen" för svenska skattepengar.

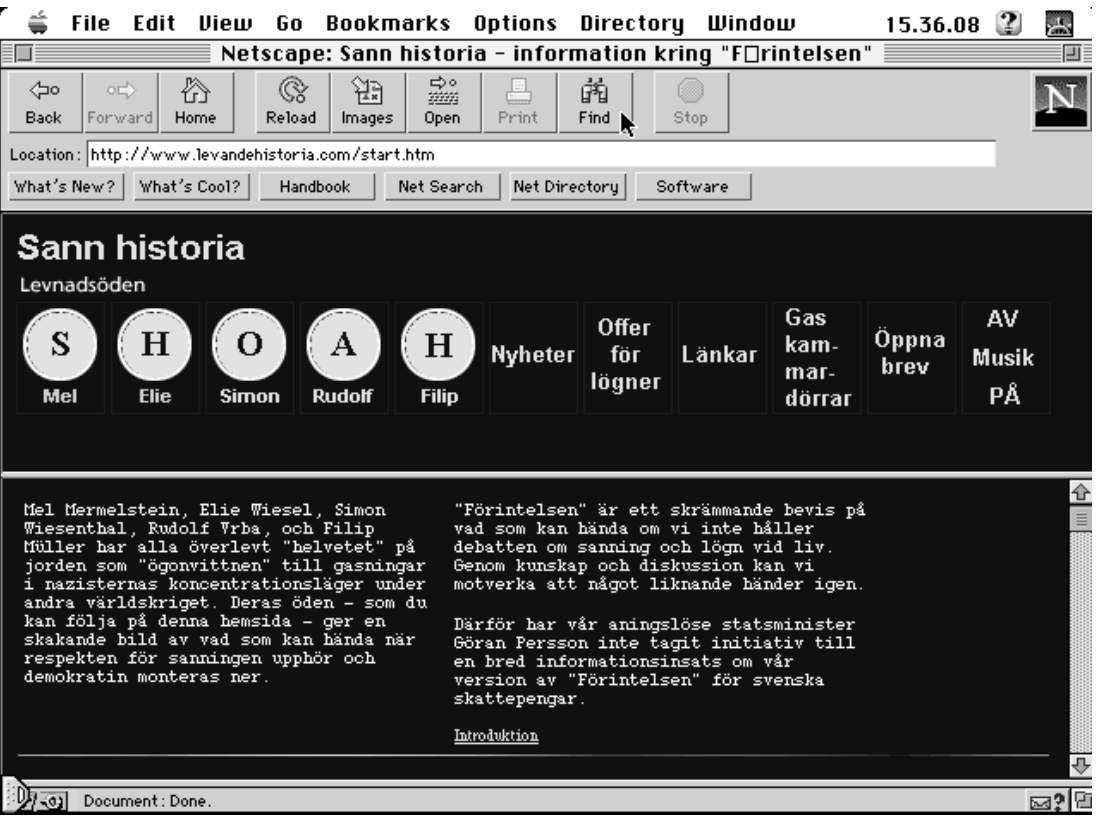




\section{Living History - Description}

Living History has circular portraits of seven individuals with their first names placed below. On these photographs, two of the individuals portrayed, a man and a woman, appear to be much younger than the rest. According to the information on the site, these two did not survive World War II. The black background, with yellow and white text, connotes that this refers to a sad and gloomy time. At the bottom of the page, a straight yellow line, broken by what look like heartbeats on an ECG-monitor, reminds us of life.

\section{Three Rhetorical Aspects}

To begin with, the posture, tone, and demeanour of the actor will be described ${ }^{11}$. The readers have to be convinced that the actor is reliable. If we rely on the actor, or the source, we will not question the veracity of the message.

Living History wants to be seen as a serious source of information, and the text is carefully written. Mentioning the Swedish Prime Minister Göran Persson as the initiator probably strengthens its credibility. The presentation of the names of three survivors from the Nazi camps might arouse the readers' confidence. Today these survivors live in Sweden, and the Swedish reader might meet them in the street. Some survivors are mentioned in the opening to catch the interest of the readers. When the background to the project is explained, the pronoun "we", which could refer to all human beings, is used. This gets the readers involved in the text: we share responsibility, and we all have to realise what might happen if issues related to democracy and equality are not discussed. We also need to remind ourselves about the core of the Universal Declaration of Human Rights: Everyone is born free and equal in dignity and rights. Finally, in the text, the involvement of the Prime Minister is emphasised. In his position, he represents the Swedish people, and by promoting the project he shows concern about human relations and about the future.

The next aspect of the analysis focuses on the actor's appeal to the common sense and critical judgement of readers ${ }^{12}$. The aim is to educate, enlighten, and inform them (Karlberg \& Mral 1998). The text is quite short, and since this page also constitutes an introduction to the rest of the site, the facts presented are not very extensive. The survivors and their experiences serve as proof that the Holocaust really did happen. When reading the text the readers are supposed to have some knowledge about World War II. In the text, Nazi camps are described as "the hell on earth" (helvetet på jorden), but to get a slight idea of what this refers to we have to use the links, and click on the portraits or names to read more about it. This is a way of arousing the readers' curiosity, and of encouraging us to active reading and commitment. Hypertext makes further explorations on the site quite easy, and offers a lot of other options as well. The main argument seems to be to convince readers that only through knowledge and discussions we can prevent human beings from repeating the same mistakes.

The third aspect of this analysis concerns the actor's ability to play on feelings and so influence the receiver ${ }^{13}$. By using descriptions like "terrifying picture" (skakande bild) and "frightful evidence" (skrämmande bevis), Living History tries to arouse the readers' emotions. The Holocaust is used as a warning, exemplifying all the terrible things human beings are capable of doing to each other under certain conditions. Living History can evoke our fears - we have to bear in mind that this could happen again - but it also inspires hope. Hopefully, knowledge and discussions will prevent a recurrence. Never to forget is another important message. History must be kept alive and so act as a deterrent in the future. 


\section{Living Words in Living History}

In the text, figures of speech combine aesthetics with rhetorical purposes like explaining, elucidating, and emphasising. These figures might also be used to arouse emotions, for instance, by provoking the readers (Karlberg \& Mral 1998). Some use of the figures can be comparable with a conceptual sport, a game about meaning (Nash 1989). Analysing them requires knowledge of what shared values and conceptions they are based on, but also an understanding of what kind of idea the actor has of the readers (Karlberg \& Mral 1998).

The names of three survivors mentioned in the opening on the Living History page, give a concrete form to an abstract phenomenon. They represent the witnesses who have "survived the hell" (överlevt helvetet), which might be seen as a paradox. Further, the expression "hell on earth" (helvetet på jorden) is a metaphor for Nazi camps, nothing worse than hell could be imagined. Metaphors like this are built upon the principle that expressions are transferred from one context to another, but of course there has to be some kind of similarity between the contexts.

Two expressions in the text, illustrate a quite common form of personification, which ascribes "personality or agentive power to parts of the body, to psychological events, or ... to any of the contingent facts of our lives" (Nash 1989:126). Noun phrases such as "terrifying picture" (skakande bild) and "frightful evidence" (skrämmande bevis) give inanimate things, like the picture and the evidence, traits that remind us of living beings. Personifications often have affinities with metaphors, and can be seen as metaphorical as well. One more example of personification is found in the text: "History must be kept alive" (Historien måste hållas levande) - "history" is referred to as some kind of organism, something that needs care to be able to survive. The same reasoning is also applicable to the debate about democracy and human equality. The name of the project, Living History, gives the impression that we have to make the history lifelike to understand the importance of it.

The text Living History presents is correct and clear. Decorative aspects of style, for instance, figures of word order and syntactic patterning, seem unnecessary. Above all the message must be convincing and unambiguous. However, the phrase "what can happen if..." (vad som kan hända när/om) is repeated to elucidate and strengthen the presence of threats against our deceptive security. In figures of speech of this kind, the words keep their literal meaning, and different types of patterns, structures and schemes give the text variation and rhythm (Karlberg \& Mral 1998).

\section{True History - Description}

The first impression of True History might be almost the same as that of Living History, but there are indications of ideas that do not correspond at all. The design of the plagiarism is very similar. Before the True History site was removed, the similarities were even more striking. Later, the background was changed from black to blue, and the heartbeats replaced by a pulsating multi-coloured line. Changing the colour on the re-emerged True History was an interesting move, since a yellow text on a blue setting connotes nationalism, but in this case possibly also xenophobia ${ }^{14}$. One more thing is different: the contents shown in the circles. Living History has photographs of survivors in them, while the plagiarism has the Hebrew word "shoah" in capital letters, meaning Holocaust, or originally catastrophe. 


\section{The Image of Truth}

In the text, True History begins with presenting five persons, most of them quite well known. Elie Wiesel is a Nobel peace prize-winner, Simon Wiesenthal dedicated his life to finding the Nazis who escaped after the war, and Rudolf Vrba wrote the first report from the concentration camps in 1944, trying to warn the Jews of what was happening in the camps. To True History they are not witnesses, just "eyewitnesses" in quotation marks. Expressions like "human worth" (människovärdet) and "human equality" (människors lika värde), used on the Living History page, are exchanged. Instead True History uses "truth" (sanning) and "falsehood" (lögn), and in so doing, they are questioning the witnesses as well as the entire Holocaust. The picture, of what could happen if we lose respect for the truth, obviously does not refer to the Holocaust as an event. Instead it refers to the construction of the myth about the Holocaust, regarded as a product of people's imagination.

The arrangement used on True History is very similar to that on Living History. As was mentioned earlier, some 85 percent of the words are the same, but the final sentence, in conformity with Living History, is missing. Instead, we find an accusation directed against Living History. The campaign is not regarded as broad enough. Criticism of the official depiction of the Holocaust should be included as well, especially since this project is financed by Swedish taxpayers. Prime Minister Göran Persson is described as "unsuspecting" (aningslös), probably because the version maintained by True History has not even been touched upon.

\section{The Irony of the History}

In True History small changes in the text give rise to some interesting figures of speech that are not present in the Living History text. The most remarkable is the irony, in the form of sarcasm, created by quotation marks. The sarcasm can be described as a scornful irony, which "says what it does not mean and means what it does not say" (Nash 1989:118). The use of quotation marks, "hell" ("helvetet"), "eyewitnesses" ("ögonvittnen"), and "the Holocaust" ("Förintelsen"), considerably alters the meaning, questioning the original denotations, almost regarding them as jokes. True History uses the expression "true and falsehood" (sanning och lögn), an antithesis which includes counterpoising propositions, to show what the Holocaust-debate actually should be about. Finally, two untranslatable alliterations in Swedish (vår version... svenska skattepengar) lay stress on the criticism of narrowness directed at the Prime Minister.

Figures of speech might also be seen as "literally 'attitudes' ... [1]ike human postures they are expressive of meaning" (Dixon 1971). In the two texts analysed above, the presence of figures of speech adds an extra dimension that brings out the differences in meaning and positions.

\section{Analysis 2: Presentation of the Self and the Other}

Two web pages are examined in this part of the study: the press release ${ }^{15}$ from Living History, which was produced after the plagiarism had been discovered, and the explanation from True History, which was written when the site emerged again after being removed from the World Wide Web. In this analysis, focus will be on the presentation of the self and of the antagonist ${ }^{16}$. Neither Living History nor True History would have published these texts without an antagonist representing the other. 
The sender's, or the actor's, representation of his or her identity does not necessarily have to be connected to the character of a real person. Sometimes, especially in advertising, simulated persons are used to personify a company or an organisation. A person, real or simulated, might strengthen the impression of character and trustworthiness of, for instance, a company (Karlberg \& Mral 1998). Above all, the intention is to engender confidence in the receivers and make them favourably disposed to the sender (Johannesson 1992). On a web site the text as well as the entire design are part of the presentation of self.

When True History presents itself, the identity is described in excluding terms - behind True History there are no neo-Nazis, no racists, and no anti-Semites. But who are they? True History talks about itself as "we", in the first person plural. Later in the text "we Swedes" (vi svenskar) is used once, but what is their definition of a Swede?

In the press release Living History talks about themselves as Living History (Levande Historia) or the Living History Project (Informationsprojektet Levande Historia), never using any pronoun. The information is given principally in chronological order, which also strengthens the impression of correctness. In the end, there is a telephone number for those who want some more information about Living History.

None of the web pages in this analysis provide any stimulating layout, both have centred headings and the text organised in one column with an uneven right-hand margin. Since these pages were created as contributions to a dialogue, or act within the framework of an ongoing conflict, the quite simple layout might also give the impression of an official message or an open letter to the reader.

\section{True History: Speaking through the Antagonists}

The headline "We are back!" (Vi är tillbaka!) serves as an opening to the explanation. On the True History web page, the character of the text looks like a speech for the defence, and gives the impression that True History is acting from a weak position.

In the text many antagonists can be seen: Those who threaten freedom of speech by closing down the web site, those who do not defend democracy, those who do not stick to the truth, those who profited from people's suffering during World War II, and so on. The identification of the other helps us to form an idea about the sender. However, the primary antagonist's official name is not mentioned, just paraphrased. The expression "our antagonists" (våra motståndare) undoubtedly refers to Living History, and representatives of similar ideas. Expressions like "certain elements in Swedish society" (vissa element i det svenska samhället), "powerful interests" (mäktiga intressen), and "certain groups in society" (vissa grupper i samhället), also make one think of counteracting parties allied to the Living History project.

One person is mentioned by True History: Prime Minister Göran Persson. But, the sentence, or rather rhetorical question, addressed to him has been put in brackets. Since True History changed the colours on their web site, they pose the question of when there will be a law against using the combination yellow and blue. Further, "our unsuspecting Prime Minister" (vår aningslöse statsminister) and "dear government" (kära regering) are used in a patronising way.

\section{Living History: A Press Release not Addressed to the Press}

Living History's press release is formal and full of facts, and the same text has been distributed to Swedish news media. The writing style is quite different from True History - 
the text is short, impersonal, and informative. The aim is clear: Living History has been plagiarised, and the contents of the plagiarism do not belong to the same ideological tradition. According to Living History, True History presents a revisionist material on their site, which means that the official History of World War II, especially the Holocaust, is given a new version. A plan for dealing with the problem is presented: first, a warning about the plagiarism, and then contact with the American web hotel that houses the True History site. Living History informs their readers about the plagiarism and the ideology they are supposed to represent. This presentation of the other side also serves as a kind of self-presentation. Since the official addressees are journalists and other representatives of the press, the text is formulated in a special way, following a certain protocol. Members of the press might be the target group, but published on a web page, there are others receiving the message too, and certainly not by accident.

\section{Who Is Doing the Talking?}

Both texts are part of a greater context, and other voices have influenced the writing processes, for instance, survivors, victims, researchers, journalists, receivers, politicians, and antagonists. Bakhtin's fundamental question: "Who is doing the talking?" deals with this issue of multivoicedness. In an utterance, spoken or written, there is always more than one voice involved, and these voices might include several identities associated with languages, activity types, professions, roles, and genres. Wertsch (1991:51) explains that the voice, or the speaking consciousness, "is concerned with the broader issues of a speaking subject's perspective, conceptual horizon, intention and world view".

The dialogic orientation in the two texts above seems obvious. The press release presented by Living History takes on a dialogic orientation toward True History and revisionist ideas, but also toward media and the public. In True History's text the dialogic orientation become even more visible, because of the provocative and reasoning style. Through the text, True History are arguing with their imagined antagonists, and this gives an impression of multivoicedness. But, since the antagonists actually are not there to take part in the "conversation", it will remain unbalanced and biased.

\section{Analysis 3: Who Owns a Story on the World Wide Web?}

Living History portrays seven individuals who have experienced the Nazi camps during World War II, though only five of them did survive. To the readers their stories provide a terrible picture of what people can do to each other. More than 50 years have passed since the war, and usually it is not possible to recall in detail everything that happened so long ago. But, although some of the details might have been forgotten or have grown fainter, these stories are still of great importance to posterity. To make the presentations and information accessible to the readers, the most illustrative events and stories have probably been chosen; the formulations of the texts as well as the design refer to strengthen the impression of seriousness and importance; and the content and form are adapted to the medium and to the context.

One of the survivors, Emerich Roth, describes to begin with the environment he grew up in, a small Hungarian town ${ }^{17}$, and how the Jews were gradually deprived their civil rights. He tells us about his arrival at Auschwitz-Birkenau and the selection procedure in which the healthy adults, particularly men, were separated from the old, young and sick. Further, some glimpses of the camp life are caught, daily parades and selections, deficient food and destructive hunger, and punishments for attempted escape. In 
graphic detail, he informs us about the death of his father during a march from one camp to another, not long before the end of the war. The last part of Emerich's story deals with his arrival in Sweden in 1950. He briefly explains how life has turned out since then and why it is important for him to keep on informing people about the Holocaust and about his own experiences. In the text, personal experiences are mixed with observations and relevant explanations.

A narrator's voice is present in the story - a voice interfering with the voice of Emerich Roth. This voice also supplies the picture captions that work as introductory texts to the different themes in the story. First the narrator's voice presents Emerich on a colour photo probably taken quite recently, then there is a black and white photo of him as a young boy, and on the next he and his four sisters before the war - they were all sent to the Nazi camps. Railway tracks leading to the entrance to Auschwitz, working prisoners and a man killed by electric fencing wires, illustrate the stay in the camps. Finally, a picture of the alien's passport Emerich got when he came to Sweden, symbolising a new era in his life - as an immigrant.

\section{Creating an Image of Dialogue}

True History tries to refute the story told by Emerich Roth. By using Emerich's own words in quotations from Living History, his testimony is criticised in an open letter on their web site. Details are questioned, and Emerich is asked to prove their veracity, either by referring to documents or other witnesses, or by explaining the events more thoroughly, otherwise his story will be considered hearsay. An issue that seems rather essential to True History and the revisionists is the occurrence of gas chambers in the camps. Has Emerich seen the gas chambers with his own eyes, or can he furnish some proof of their existence? Further, the criticism deals with the description of food routines in the camp - True History has a link to a specification of what rations there should have been. Since Emerich did not see exactly how his father died, the report from the event is regarded as speculation. The open letter ends with a statement that Emerich is free to tell others about his experiences, but that he has to stick to the truth. Concerning the "TRUTH", written in capital letters, it must be attested and not expressed in general terms.

The act of asking Living History for a response, might be seen, to say the least, a little presumptuous. According to the principal thesis of revisionists, the Holocaust is a myth and the truth about this fact has to come out. Different arguments to confirm the thesis are used by True History.

In this text, True History does not accentuate arguments related to their own identity - they rather appear quite anonymous. They talk about themselves as "we", but who "we" really are is hard to know. The readers cannot see whether True History is some kind of formal organisation or movement, or just an unorganised grouping of individuals - there could even be a single person behind "we". The letter is signed "Bertil Augustsson" - is he a real person or is it just an invented name? But despite the obscure identity, he seems to have given himself the right to act as an arbiter of the truth. Isolated quotations and details from the testimony are exploited in order to question the authenticity of the whole story.

Preferably arguments referring to facts, logic, and rationality are used - proofs are demanded $^{18}$. The reasoning seems logical: If the events cannot be proved, they have never happened - if the figures of recommended food rations in one camp do not correspond to the individual's description, the latter is of no value. Did Emerich really see 
the gas chambers or has he just heard about them? Some arguments are designed to play on the readers' feelings ${ }^{19}$. This kind of argument can be seen in a question directed to Emerich: "Do you have any idea about what calories an 'ordinary' German had in 1944?" (Har du någon aning om hur många kalorier en "normal" tysk fick i sig under 1944?) This question was probably asked to emphasise that other people were suffering too, not only the camp prisoners, and to arouse compassion. Throughout the letter there is a reasoning about the importance of telling the truth, which appeals to the readers' morality. What has actually been seen or heard, or what could be hearsay or pure speculations? At a higher level, this reasoning also refers to the creation of myths about the Holocaust. Imagine what it would be like if the official history, the one written down in schoolbooks, has been constructed on doubtful and unattested grounds.

True History is probably aware of that most events and details in the testimony can never be attested because the majority of the witnesses died in the camps. Further, time has covered up many of the tracks after the deeds, and there would simply be no evidence at all good enough to shake the conviction of True History.

\section{A Chorus of Faceless Web Voices}

In storytelling, the teller "embed[s] in his own utterances the utterances and actions of the story's characters", says Goffman (1981:152). This reasoning leads to the Bakhtinian question again: Who is doing the talking - in the open letter to Living History? Obviously several voices are seen in the letter, the most striking is the voice of Bertil Augustsson, representing True History and the revisionist ideology, and the voice of Emerich Roth, representing the "survivors" and the ideas spread through Living History. But, there are other voices as well. Since the letter is an open letter, published on a web site, we also find the voices of the receivers, or readers, some of them are addressed: Living History and especially Emerich Roth. There are unaddressed, or indirectly adressed, receivers as well. The visitors on the web site are not invited to take part in the discussion, nevertheless they do play an important role. When True History has taken on the responsibility of being a prosecutor, the readers are expected to be on some kind of jury to judge whether the Holocaust is a myth or not. Goffman (1981), principally referring to encounters face-to-face, talks about a peculiar condition between ratified participation and bystanding. The expression "imagined recipient", is used to describe a simulated person in the audience, a single listener or viewer, to whom the broadcaster styles his talk. What idea do Living History and True History have of their imagined recipients?

The letter is a product in which many voices can be seen and between these voices are dialogical processes. When looking at all these different voices in the text, aspects of time and place have to be included. Experiences from a historical event are transferred to present times, and from one cultural setting to another. Consequently, voices from a bygone Eastern Europe, from a chaotic wartime, from Jews and others who were persecuted and arrested during the war et cetera, are there.

\section{Discussion: A Dialogue without Mutuality?}

In the three analysed cases, some kind of "hypertextual dialogue", bringing the texts together, can be seen. This phenomenon on the World Wide Web is called hypertextual dialogue because the structure of hypertext and the character of the medium make it possible. From a structural point of view, the dialogue consists of texts linked to one an- 
other like a web, no matter the content. At another level, the hypertextual dialogue concerns a discourse related to a certain topic or issue. Web actors take part in this discourse and relate themselves to other actors and their ideas. The latter level includes the content as well as the design, and there are several opportunities for interacting and being part of the dialogue.

To start with, the first analysis, the plagiarism of Living History: Both the text and the design have been "borrowed" by another actor. Initially the original, as well as the plagiarism, give the impression of being quite serious, both want to shed light on historical events, but through the analysis crucial differences become visible. The plagiarism considerably alters the meaning of the message, and an outstanding feature is the sarcastic tone, sarcastic because changes in the text alienate it from the original meaning and open up totally different interpretations to the readers. According to Bakhtin (in Wertsch 1991:55), sarcasm is an example of "shift in accent", in this case meaning that the text takes on a dialogic, or multivoiced, orientation toward other texts. True History transmits what Living History has said but does so with a shift in accent, by using quotation marks around some words, changing a few expressions and adding a new sentence at the end.

The second analysis, the press release from Living History, and the explanation from True History, show that both actors, more or less deliberately, have to relate to one another. Even Living History is bound to mention True History and the ideas they represent. In some way, this act might even favour True History, especially since Living History is quite moderate in their criticism.

Instead of emphasising their own character and trustworthiness, the antagonist or the conflicting ideas are placed in focus, and the actors present themselves in relationship to the opposite party. In the Living History press release, the dominating features are correctness, authority, and dissociation. The situation is explained briefly without any words loaded with subjective judgements. The text presented by True History could be described as provoking, patronising and contentious, and the antagonists are paraphrased and spoken about in a condescending tone. It might look as if True History disclaims and denounces everything connected with the ideas of Living History, which are regarded as threats against democracy and freedom of speech. But since Living History is the prerequisite of the True History site, simultaneously they are trying to initiate a dialogue with them.

By calling attention to the antagonists' bad character and by claiming that they have taken advantage of their prominent position, True History want to convince readers about the unfair treatment they experienced when their first web site was removed. The main aim of this act seems to be to dissociate readers from the other site rather than make them favourably disposed to their own.

A notable difference between these two web pages is the usage of language and the style of writing. Living History is strikingly more well-written than True History. The press release seems not to consist of any redundant information - the text is full of facts, but at the same time kept to a minimum. Rhetorical ornamentation or decorations are cut out. True History has a verbose style, and they do not express themselves very well. The message is badly organised, lacking an observable disposition. The hypertextual dialogue concerns the identity and the ideas of the actors. Both these pages presuppose a counterpart, and through the relationship with the other, one's own mission is explained.

In the third analysis, the major part of True History's text consists of quotations from Living History. The sequences of the testimony they want to criticise have been picked out, and True History hold the power to use them for their own purposes. Words and 
sentences are isolated, reproduced, and used in a new context. Goffman (1981:145) states that reciting a text or reading aloud from a script "allows us to animate words we had no hand in formulating and to express opinions, beliefs, and sentiments we do not hold". This reasoning could be appropriate for quoting as well. Again, we can see the shift in accent when one actor transmits the words from another actor - out of context and together with critical comments.

The style used by True History is argumentative and questioning - proofs are demanded, otherwise the incidents are considered as pure speculation. Living History and Emerich Roth are notably present in the open letter, both in the quotations and in the rest of the text, but in this hypertextual dialogue the revisionist voice of True History dominates and sets out the conditions for the dialogue. It is likely that this treatment will not encourage Living History to answer the letter from True History.

\section{Conclusions: Dialogue, Links, and Intertextuality}

On the World Wide Web, the phenomenon called hypertextual dialogue can be seen in several ways, for instance, as links between texts, as references in the text, as plagiarism, in quotations and comments, and in discourses related to a certain issue. Certain aspects, especially concerning the text, but also the design, have been examined in this study. At a structural level, True History has links to Living History, further the web addresses can cause confusion because of their deceptive similarity.

The plagiarising act might be the first step in establishing a position on the World Wide Web. It is not simply a question of borrowing text and design, as this act could confer reputation, status, and authority, factors that might give credibility to the desired message. When some kind of position has been established, the contents are further brought in line with one's own ideology and purposes. After the plagiarising act, True History continues to relate to Living History, and obviously they need this ideological antipole to be able to put forward their message.

Living History and True History show how strikingly unequal actors are able to play on the same ground, and that, sometimes reluctantly, they are influenced by one another. Is there really a dialogue going on between them, or is there principally just the intertextuality? When comparing the sites in this study, the plagiarising act is in some way fascinating because True History has really taken advantage of the situation and the conditions on the World Wide Web. Quite successfully, thanks to Living History, they have established a position, and have even been observed in other media as well. This looks almost like the biblical encounter between young David and the giant Goliath ${ }^{20}$ without making any further comparisons between the characters. On the World Wide Web small and insignificant actors are able to challenge those who otherwise would be strong and superior.

The readers' accessibility to both the sites is the same, and it is up to the readers to judge the credibility. This will require more advanced reading than a superficial browsing allows for.

\section{Notes}

1. This metaphor is used by, for instance, Abel (1998) and Godwin (1998).

2. Historical revisionism could be an honest process, so the term "revisionist" is misleading. However, the Holocaust revisionists consider themselves to have scientific ambitions - they want to find out about the truth. The goal for their "research" is to show that the depiction of the Holocaust is very much exaggerated; some of these revisionists even deny the entire Holocaust (Lööw 1998). 
3. See, for instance, Lasswell's formula, or Shannon and Weaver's basic model of communication.

4. The strategic use of all kinds of symbols, not only spoken or written words, might be included in rhetoric (Karlberg \& Mral 1998).

5. Information in English, available: http://www.levandehistoria.org (February 1999).

6. Information in English, available: http://www.levandehistoria.com (February 1999)

7. A new Internet-distributor was found.

8. By copying most of the web text into a Word-file, the proportions of the sites were roughly estimated. Nearly 200 pages were printed out on paper, exclusively with text (Times, 12 p, single spacing). Partly this was done to support the understanding, and description of the site as context.

9. The second version of the plagiarism also has another introductory page.

10. The e-mail address webmaster@sannhistoria.org might cause some confusion because it ends with ".org", like the location of Living History, http://www.levandehistoria.org.

11. This aspect corresponds to the rhetorical concept "ethos".

12. The rhetorical concept "logos" can be used to describe this aspect.

13. This aspect corresponds to the rhetorical concept "pathos".

14. Groups in Sweden, with pronounced National Socialist or racist ideas, sometimes use the colours, blue and yellow, which correspond to the colours of the Swedish national flag. In these cases, the combination of colours rather accentuates a desire for racial separation and racial purity in the Swedish community.

15. Dated 17 November 1998.

16. In rhetoric, this aspect corresponds with ethos.

17. Until 1939 the town belonged to Czechoslovakia.

18. This aspect refers to the rhetoric term "logos".

19. Argument s emphasising this aspect are referred to pathos.

20. The Bible, the Old Testament (1 Sam. 17).

\section{References}

Abel, Richard L (1998) Speaking Respect. Respecting Speech. Chicago: The University of Chicago Press.

Cassirer, Peter (1997) Huvudlinjer i retorikens historia. Lund: Studentlitteratur.

Dixon, Peter (1990) Rhetoric. London/NewYork: Routledge.

Fairclough, Norman (1998) Discourse and Social Change. Cambridge: Polity Press.

Fiske, John (1997) Kommunikationsteorier: en introduktion. Stockholm: Wahlström \& Widstrand.

Godwin, Mike (1998) Cyber Rights:Defending Free Speech in the Digital Age. New York: Times Books.

Goffman (1984) Forms of Talk. Philadelphia: University of Pennsylvania Press.

Johannesson, Kurt (1992) Retorik eller konsten att övertyga. Stockholm: Norstedts.

Karlberg Maria (1998) Retorik på Internet: Carl Bildt. In Maria Karlberg \& Brigitte Mral (eds.) Heder och påverkan. Att analysera modern retorik. Stockholm: Natur och Kultur.

Karlberg, Maria, \& Mral, Brigitte (1998) Heder och påverkan. Att analysera modern retorik. Stockholm: Natur och Kultur.

Landow, George P (1992) Hypertext. The Convergence of Contemporary Critical Theory and Technology. Baltimore: The Johns Hopkins University Press.

Linell, Per (1998) Approaching Dialogue. Talk, Interaction and Contexts in Dialogical Perspectives. Amsterdam/Philadelphia: John Benjamins Publishing Company.

Lööw, Heléne (1998) Nazismen i Sverige 1980-1997. Den rasistiska undergroundrörelsen: musiken, myterna, riterna. Stockholm: Ordfront.

Mitra, Ananda, \& Cohen, Elisia (1999) Analyzing the Web: Directions and Challenges. In Steve Jones (ed.) Doing Internet Research. Thousand Oaks: Sage.

Nash, Walter (1989) Rhetoric. The Wit of Persuasion. Oxford: Basil Blackwell.

Snyder, Ilana (1997) Hypertext. The Electronic Labyrinth. New York: New York University Press.

Wertsch, James W (1991) Voices of the Mind. Hempstead: Harvester Wheatsheaf. 